\title{
SUITABILITY ASSESSMENT OF TWO TYPES OF HEAT EXCHANGERS FOR HIGH TEMPERATURE, NATURALLY CIRCULATING HELIUM COOLING LOOP
}

\author{
DZIANIK František ${ }^{1}$, GUŽELA Štefan ${ }^{1}$, PUŠKÁŠOVÁ Eva ${ }^{1}$ \\ ${ }^{1}$ Slovak University of Technology in Bratislava, Faculty of Mechanical Engineering, Institute of Process \\ Engineering, Nám. slobody 17, 81231 Bratislava, Slovakia, \\ e-mail: frantisek.dzianik@stuba.sk, stefan.guzela@stuba.sk,eva.puskasova@stuba.sk
}

\begin{abstract}
The paper presents a comparison of the process properties of two types of the heat exchangers designed for the heat removal from a high temperature helium cooling loop with steady natural circulation of helium. The first considered heat exchanger is a shell and tube heat exchanger with U-tubes and the other one is a helical coil heat exchanger. Using the thermal and hydrodynamic process calculations, the thermal performance of the two alternative heat exchangers are determined, as well as the pressure drops of flowing fluids in their workspaces. The calculations have been done for several defined operating conditions of two considered types of heat exchangers. The operating conditions of heat exchangers correspond to the certain helium flow rates.
\end{abstract}

KEYWORDS: helium cooling loop, heat exchangers, thermal characteristics, heat transfer calculation, pressure drops calculation

\section{Introduction}

An important area of nuclear energy research is currently also the development of new technologies characterised by improved efficiency, increased safety and reliability as well as lower radioactive waste production. New types of the nuclear power reactors are a part of these technologies. The perspective types of nuclear reactors are also the gas-cooled fast reactors (GFR) which rank among the so-called Generation IV reactors. A suitable heat transfer medium of the primary circuit system and the decay heat removal system in such gascooled fast reactors appears helium. For this reason, the research of helium cooling loop systems is very topical. The research activities in the given area from several aspects are documented in the various publications, as for example $[1,2,3,4,5,6,7,8,9,10]$.

The cooling loop systems can be divided from a process point of view into the systems with forced or natural circulation of the cooling fluid. The operation of such cooling loop systems is based on a combination of thermal and hydrodynamic processes that are interdependent. A very significant influence on the qualitative and quantitative side of the thermo-hydrodynamic processes has the geometric configuration of the system. For the efficient operation of cooling systems with the natural circulation of the primary cooling fluid, it is important to minimise the consumption of mechanical energy in the natural circulation. In this regard, it is necessary to use a suitable type of the heat exchanger intended for heat removal from the primary cooling fluid. An example of a high temperature helium cooling loop allows the suitability assessment of the two types of heat exchangers, based on the thermo-hydrodynamic process calculations. The first considered heat exchanger is a shell and tube heat exchanger with U-tubes and the other one is a helical coil heat exchanger. Thermohydrodynamic process calculations of both heat exchangers have been performed for the operating conditions of cooling loop with steady natural circulation of helium. This cooling 
loop can be defined as a model of passive safety feature serving to emergency heat removal from the fast reactor working space (the active zone of gas-cooled fast reactor). Such a type of helium cooling loop is one of the research subjects in our department $[4,7,9]$.

\section{The characteristic of assessed heat exchangers designed for the heat removal from a high temperature naturally circulating helium cooling loop}

Based on the thermo-hydrodynamic process calculations of the heat exchangers, a comparison of the operating properties of two types of assessed heat exchangers have been performed in terms of their suitability for the heat removal from a high temperature, naturally circulating helium cooling loop (Fig 1). The model cooling loop consists of four main components: model of gas-cooled fast reactor (1), model of the heat exchanger for decay heat removal (2), hot piping branch (3) and cold piping branch (4). The GFR model is used to simulate a source of decay heat generated by electric heating through heating elements (rods). The model of DHR heat exchanger is used for the heat removal which is generated in the reactor model. The GFR model and the heat exchanger model are interconnected through the hot piping branch and the cold piping branch. The primary heat transfer fluid is helium. The secondary cooling fluid in the DHR heat exchanger model is water. The cooling water flows in the tube side and helium in the shell side of the heat exchanger model.

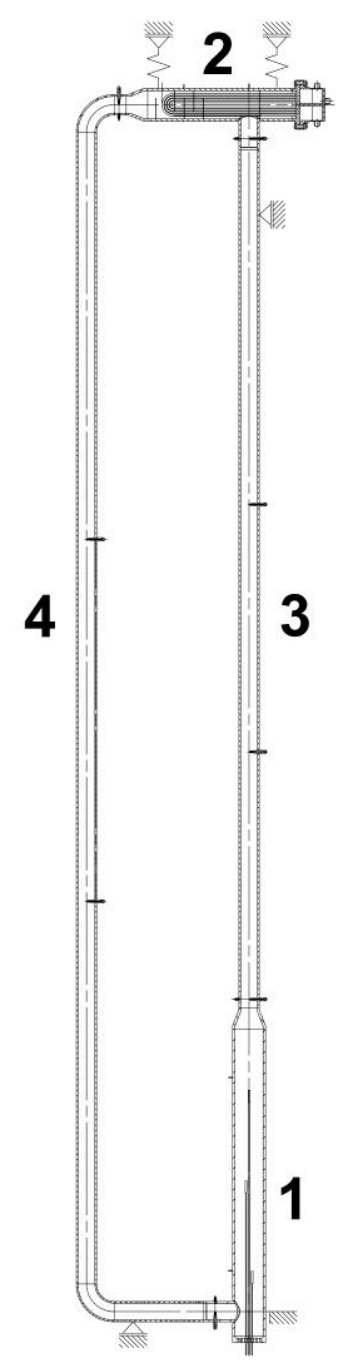

Fig. 1 High temperature helium cooling loop [4] (1 - GFR model, 2 - DHR heat exchanger model, 3 - hot piping branch, 4 - cold piping branch). 
The helium cooling loop must ensure a passive heat removal from the reactor model, i.e., it must be achieved a sufficiently intensive natural circulation (circulation caused by the effect of gravity) of helium in the cooling system due to a helium density difference in the cold and hot piping branch. Within such helium circulation the appropriate thermo-hydrodynamic conditions have to be achieved in the DHR heat exchanger model in order to ensure the desired heat flow rate removal from helium to the cooling water.

The first considered type of the DHR heat exchanger model is a shell and tube heat exchanger with U-tubes (Fig 2). From a design point of view, this is a heat exchanger with a tube bundle located inside a cylindrical shell $\varnothing 273 \times 20 \mathrm{~mm}$. The helium section of cylindrical shell is made of low alloy heat resistant steel. The cooling water section of shell as well as the tube bundle and the tube sheet are made of stainless steel. The tube bundle consists of twenty U-tubes $\varnothing 16 \times 1.5 \mathrm{~mm}$ with a length of $2.2 \mathrm{~m}$, which are fixed in the tube sheet. The heat exchanger shell side internals consists of some segmental baffles (baffle spacing $80 \mathrm{~mm}$ ) to direct the flow of helium and to support the tubes.

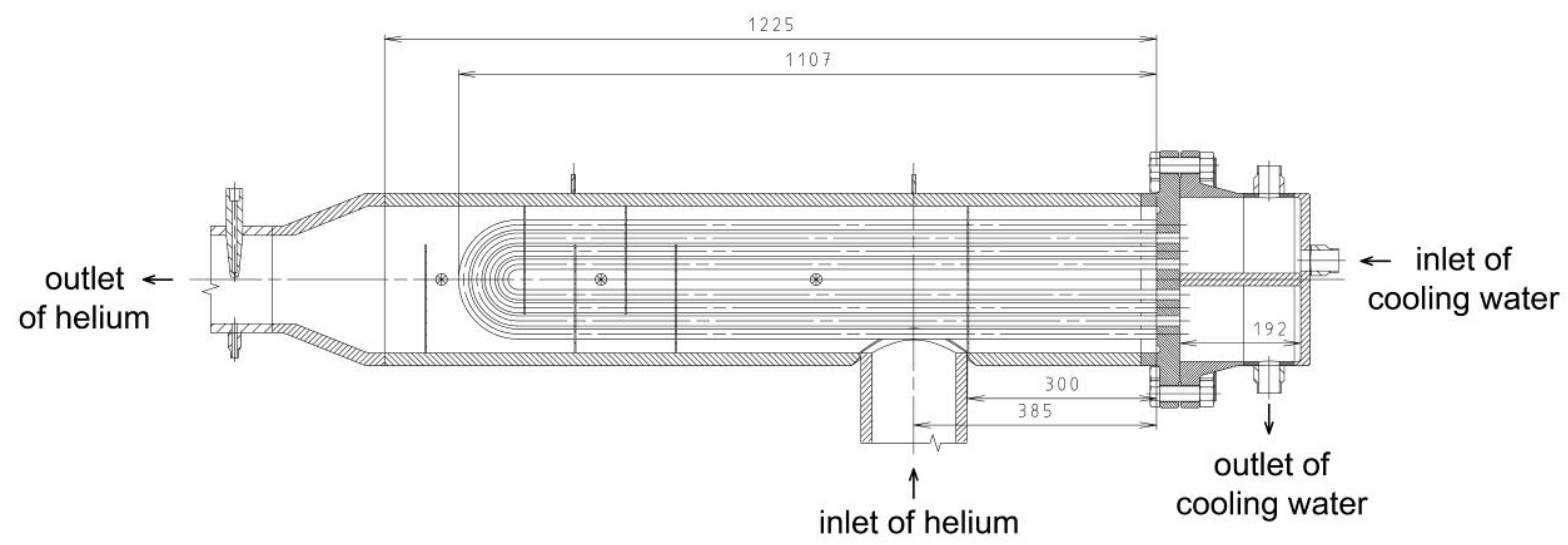

Fig. 2 The shell and tube heat exchanger with U-tubes [4].

The second considered type of the DHR heat exchanger model is a helical coil heat exchanger (Fig 3). A helically coiled tube $\varnothing 26 \times 2 \mathrm{~mm}$ with a total length of $21 \mathrm{~m}$, which is made of stainless steel, is located inside a cylindrical shell $\varnothing 273 \times 20 \mathrm{~mm}$. The average diameter of the coil winding is $190 \mathrm{~mm}$ and its pitch is $30 \mathrm{~mm}$. The cylindrical shell of a helical coil heat exchanger is made of low alloy heat resistant steel. Both of the considered heat exchangers have approximately the same external design dimensions and the same size of the heat exchange area $1.553 \mathrm{~m}^{2}$. 


\section{outlet of cooling inlet of cooling}

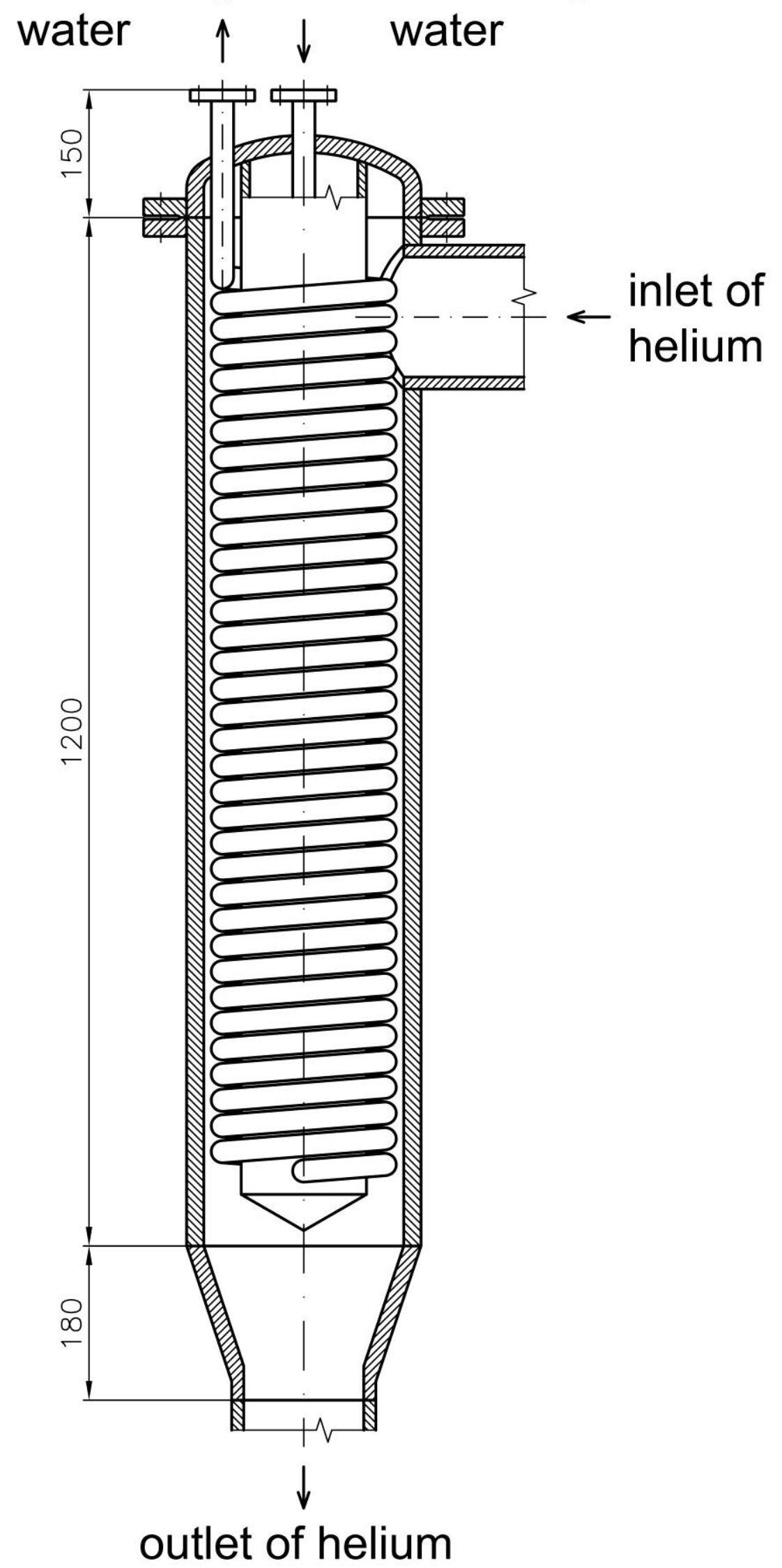

Fig. 3 The helical coil heat exchanger. 


\section{Methodology and the conditions of thermo-hydrodynamic calculations of heat exchangers}

Thermo-hydrodynamic process calculations of two types of heat exchangers (a shell and tube heat exchanger with U-tubes and a helical coil heat exchanger) designed for the heat removal from a high temperature helium cooling loop (e.g. DHR heat exchangers) have been performed for the defined operating conditions, as listed in Tab. 1. The necessary mass flow rates of helium and cooling water follow from the thermal calculations of the heat exchangers. Based on the mass flow rates of helium $m_{H e}$ and cooling water $m_{W}$, it is possible by the hydrodynamic calculations to determine the values of the pressure drops in the heat exchangers for helium $\Delta p_{d H e}$ and for cooling water $\Delta p_{d W}$. The methodology of process calculations of heat exchangers may be found in the various specialised publications $[11,12$, $13]$.

For the thermal calculation of the heat exchangers, the balance equations of the enthalpy

$$
\begin{gathered}
Q=m_{H e}\left(h_{H e I}-h_{H e O}\right)=m_{H e} \bar{c}_{p H e}\left(T_{H e I}-T_{H e O}\right), \\
Q=m_{W}\left(h_{W O}-h_{W I}\right)=m_{W} \bar{c}_{p W}\left(T_{W O}-T_{W I}\right),
\end{gathered}
$$

as well as the kinetic equation for the heat flow $Q$ between helium and cooling water through the heat exchange wall of the heat exchanger

$$
Q=A k \varepsilon_{\Delta \bar{T}} \Delta \bar{T}_{\mathrm{ln}}
$$

Tab. 1 Defined operating conditions for thermo-hydrodynamic process calculations of two

\begin{tabular}{|c|c|c|}
\hline Parameter & Symbol & Value \\
\hline Operating pressure of helium & $p_{H e}(\mathrm{MPa})$ & 7 \\
\hline Heat exchange area of the heat exchanger model & $A\left(\mathrm{~m}^{2}\right)$ & 1.553 \\
\hline $\begin{array}{l}\text { Mean value of the thermal conductivity coefficient of the heat } \\
\text { exchange wall }\end{array}$ & $\begin{array}{c}\bar{\lambda} \\
\left(\mathrm{W} \cdot \mathrm{m}^{-1} \cdot \mathrm{K}^{-1}\right)\end{array}$ & 15 \\
\hline Temperature of helium at the inlet of the heat exchanger model & $T_{\text {HeI }}\left({ }^{\circ} \mathrm{C}\right)$ & 520 \\
\hline Temperature of cooling water at the inlet of the heat exchanger model & $T_{W I}\left({ }^{\circ} \mathrm{C}\right)$ & 15 \\
\hline Temperature of cooling water at the outlet of the heat exchanger model & $T_{W O}\left({ }^{\circ} \mathrm{C}\right)$ & 45 \\
\hline
\end{tabular}
types of the heat exchangers designed for the heat removal from a high temperature helium cooling loop.

are used. The equations (1) and (2) contain the following variables related to the solved heat exchangers: the mass flow rates of helium $m_{H e}$ and cooling water $m_{W}$, specific enthalpies of helium at the inlet $h_{\mathrm{HeI}}$ and at the outlet $h_{\mathrm{HeO}}$, specific enthalpies of cooling water at the inlet $h_{W I}$ and at the outlet $h_{W O}$, mean values of the specific heat capacities of helium $\bar{c}_{p H e}$ and of cooling water $\bar{c}_{p W}$, the temperatures of helium at the inlet $T_{\mathrm{HeI}}$ and at the outlet $T_{\mathrm{HeO}}$ and the temperatures of cooling water at the inlet $T_{W I}$ and at the outlet $T_{W O}$. In the equation (3), $A$ is the heat exchange area of the heat exchangers, $k$ is the mean value of the overall heat transfer coefficient which can be expressed by the equation 


$$
k=\frac{1}{\frac{1}{\bar{\alpha}_{H e E}}+\frac{b}{\bar{\lambda}}+\frac{1}{\bar{\alpha}_{W E}}}
$$

for the thin-walled tubes forming the heat exchange wall of the heat exchangers, $\Delta \bar{T}_{\mathrm{ln}}$ is the mean logarithmic temperature difference

$$
\Delta \bar{T}_{\mathrm{ln}}=\frac{\left(T_{H e E I}-T_{W E O}\right)-\left(T_{H e E O}-T_{W E I}\right)}{\ln \frac{T_{H e E I}-T_{W E O}}{T_{H e E O}-T_{W E I}}}
$$

and $\varepsilon_{\Delta \bar{T}}$ is the correction factor of the mean logarithmic temperature difference for a given heat exchanger design arrangement. In the equation (4), $\bar{\lambda}$ is the mean value of the thermal conductivity coefficient of the heat exchange wall and $b$ is the thickness of the heat exchange wall. Mean values of the heat transfer coefficients on the helium side $\bar{\alpha}_{H e}$ and on the cooling water side $\bar{\alpha}_{W}$ of the heat exchanger model can be determined using the similarity theory. The dimensionless heat transfer coefficient is most commonly expressed in the form of the Nusselt number $\mathrm{Nu}$, which is defined by the equation

$$
\mathrm{Nu}=\frac{\bar{\alpha} L}{\lambda_{f}}
$$

where $L$ is the characteristic dimension and $\lambda_{f}$ is the thermal conductivity of the fluid. Based on the similarity methods, the general functional relationship for the convective heat transfer can be written in the form: $\mathrm{f}\left(\mathrm{Nu}, \mathrm{Fo}, \mathrm{Re}, \mathrm{Gr}, \mathrm{Pr}, s_{1}, s_{2}, s_{3}, \ldots\right)=0$. The meaning of the variables in this relationship is as follows: Fo is the Fourier number, Re is the Reynolds number, $\mathrm{Gr}$ is the Grashof number, Pr is the Prandtl number and $s_{1}, s_{2}, s_{3}, \ldots$ are the other dimensionless parameters. On the basis of these mentioned relations, it is possible by the thermal calculation to determine the values of the mass flow rates of helium $m_{\mathrm{He}}$, the temperatures of helium at the outlet of the heat exchanger $T_{\mathrm{HeO}}$ and the mass flow rates of cooling water $m_{W}$ for given values of the transferred heat flow rates $Q$ in the heat exchangers. The thermal calculation assumes the constant values of the following variables: the pressure of helium in the heat exchanger $p_{H e}$, the temperature of helium at the inlet of the heat exchanger $T_{H e I}$, the temperature of cooling water at the inlet of the heat exchanger $T_{W I}$ and the temperature of cooling water at the outlet of the heat exchanger $T_{W O}$.

The hydrodynamic calculation of the heat exchangers includes the determination of the pressure drops due to friction and the local pressure drops in each working space of the heat exchangers. The total pressure drops $\Delta p_{d}$ in each working space of the heat exchangers are the sum of the frictional $\Delta p_{d f}$ and local $\Delta p_{d l}$ pressure drops in these spaces $\left(\Delta p_{d}=\Delta p_{d f}+\Delta p_{d l}\right)$. The frictional pressure drop $\Delta p_{d f}$ is possible to calculate for flow of fluid in the straight or curved duct theoretically, using the equation:

$$
\Delta p_{d f}=\lambda_{h} \frac{L}{D} \rho \frac{v^{2}}{2},
$$


where $\lambda_{h}$ is the friction factor, $L$ is the length of the duct, $D$ is the characteristic internal diameter of the duct, $v$ is the characteristic velocity of fluid in the duct and $\rho$ is the density of the flowing fluid. Generally, the value of the friction factor $\lambda_{h}$ depends on the value of the Reynolds number Re and on the duct geometry. The following equation has been used to calculate the local pressure drops $\Delta p_{d l}$ in the working spaces of the heat exchangers:

$$
\Delta p_{d l}=\zeta \rho \frac{v^{2}}{2}
$$

In equation (8), the values of local drag coefficient $\zeta$ depend mainly on the geometric configuration of the objects in the working spaces of the heat exchangers which cause the local hydraulic resistances to fluid flow.

\section{Results}

The results of thermal and hydrodynamic process calculations of the shell and tube heat exchanger with U-tubes and of the helical coil heat exchanger present a comparison of the magnitudes of transferred heat flow rates between helium and cooling water in the two alternative heat exchangers, as well as the pressure drops of flowing fluids in their workspaces. The results also show the calculated values of some important process and operating parameters of the heat exchangers (e.g. the overall heat transfer coefficient and the temperature of helium at the outlet of the heat exchanger). The calculations have been done for several defined operating conditions of two considered types of heat exchangers. The operating conditions of heat exchangers correspond to the certain helium flow rates. The results of the calculations are presented in the form of graphs.

The Fig. 4 shows a comparison of the transferred heat flow rates $Q$ between helium and cooling water in the heat exchanger with U-tubes and in the helical coil heat exchanger at different helium mass flow rates $m_{\mathrm{He}}$. The influence of the helium mass flow rate $m_{\mathrm{He}}$ on the mean value of the overall heat transfer coefficient $k$ in the heat exchangers and on the helium temperature at the outlet of the heat exchangers $T_{\mathrm{HeO}}$ is shown in the Fig. 5 and in the Fig. 6 respectively. 


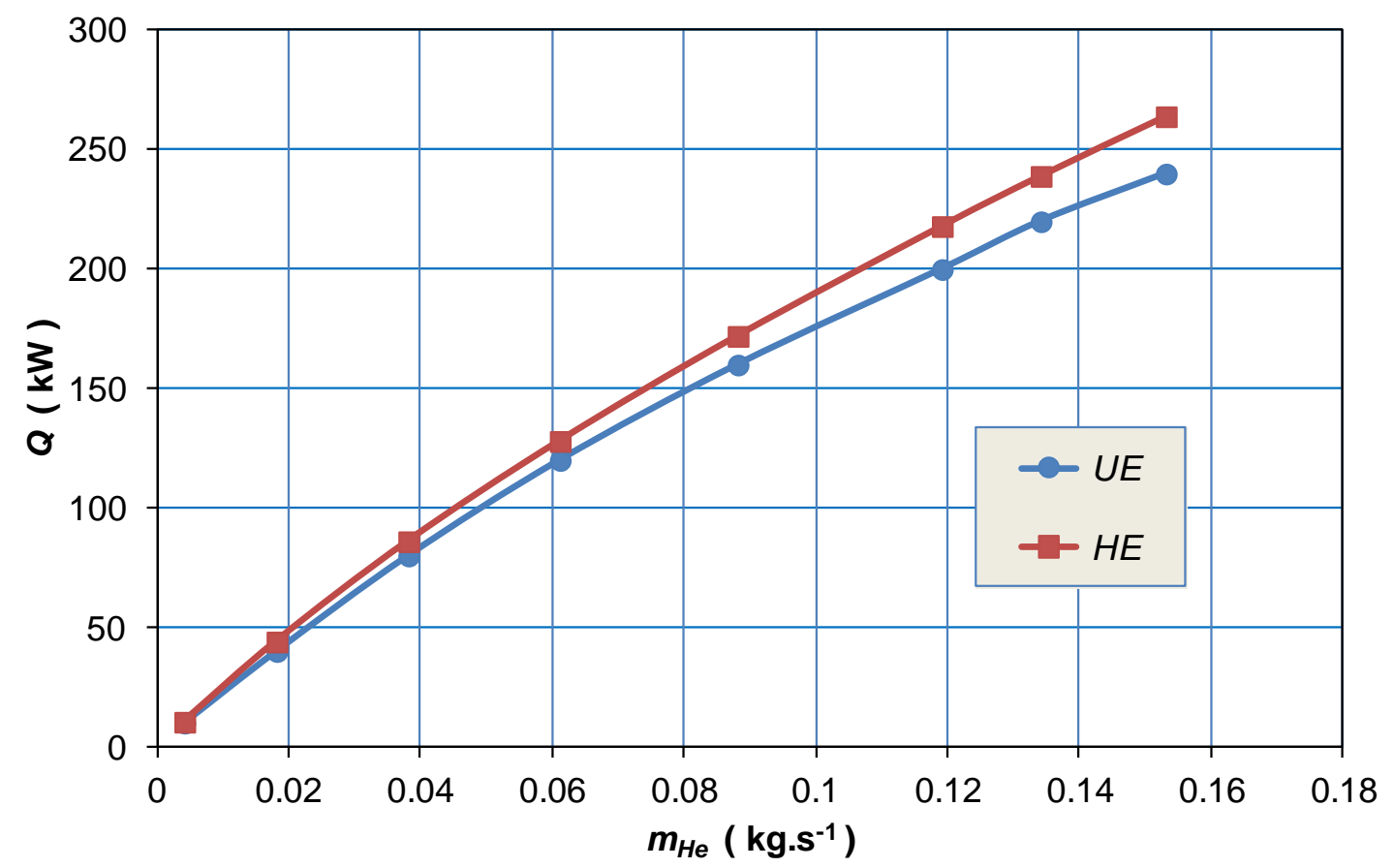

Fig. 4 The comparison of the transferred heat flow rates at different helium mass flow rates in the heat exchanger with U-tubes $(U E)$ and in the helical coil heat exchanger $(H E)$.

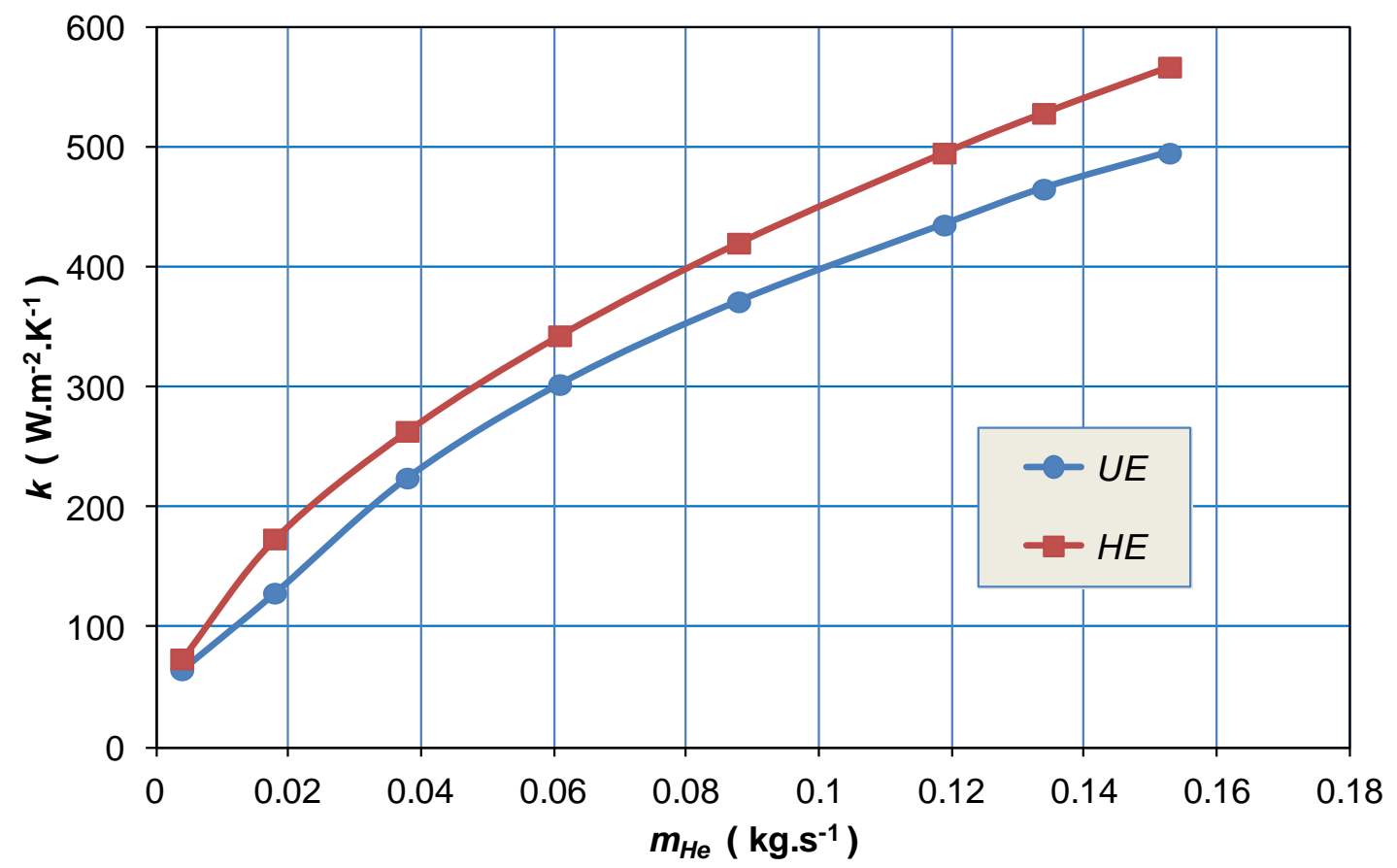

Fig. 5 The influence of the helium mass flow rate on the overall heat transfer coefficient in the heat exchanger with U-tubes $(U E)$ and in the helical coil heat exchanger $(H E)$. 


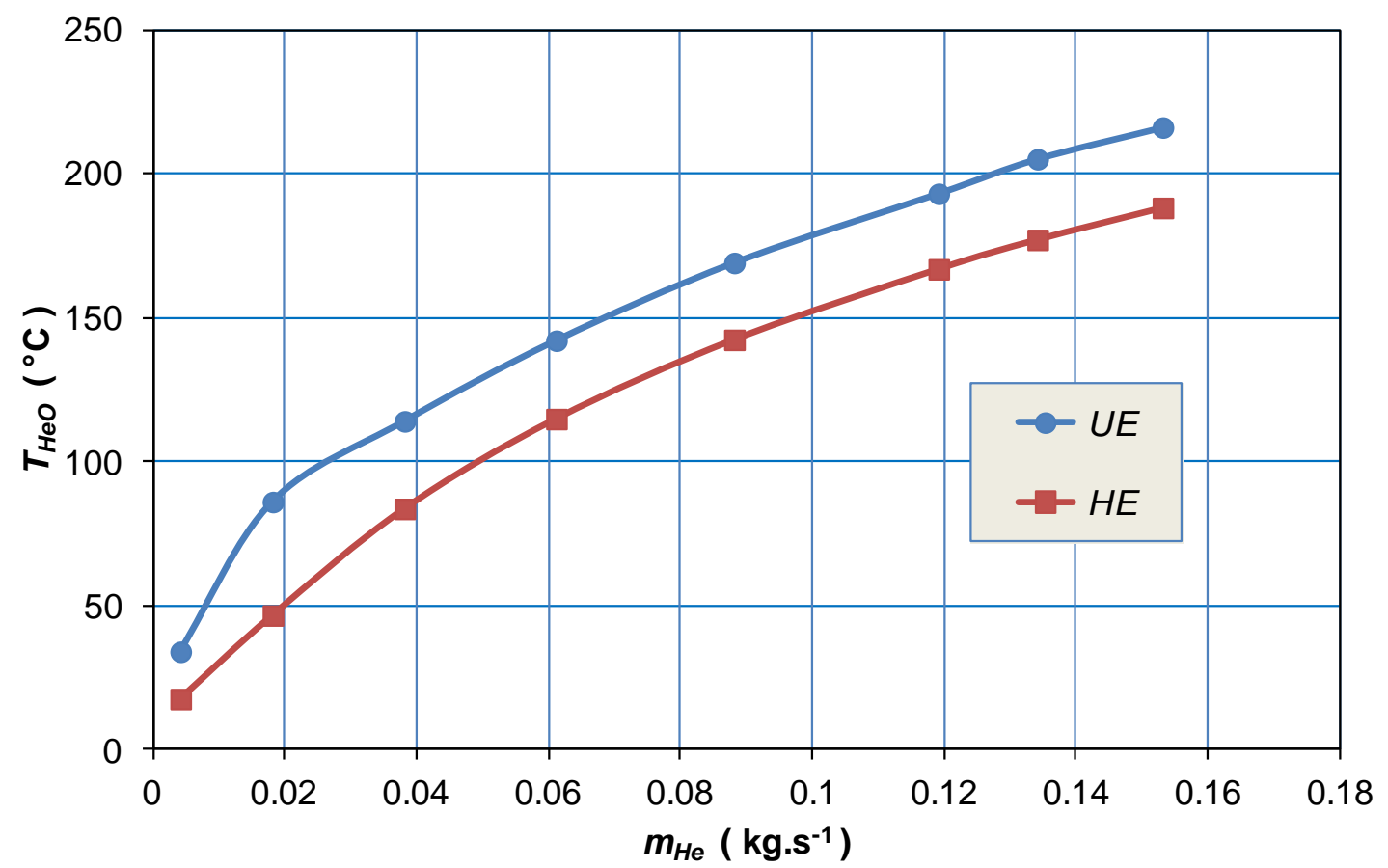

Fig. 6 The influence of the helium mass flow rate on the helium temperature at the outlet of the heat exchanger with U-tubes $(U E)$ and in the helical coil heat exchanger $(H E)$.

In the Fig. 7, the dependences of the pressure drops in the shell side of the heat exchangers for helium $\Delta p_{d H e}$ on the helium mass flow rate $m_{H e}$ are plotted, and the Fig. 8 shows the dependences of the pressure drops in the tube side of the heat exchangers for cooling water $\Delta p_{d W}$ on the mass flow rate of the cooling water $m_{W}$ under the given conditions.

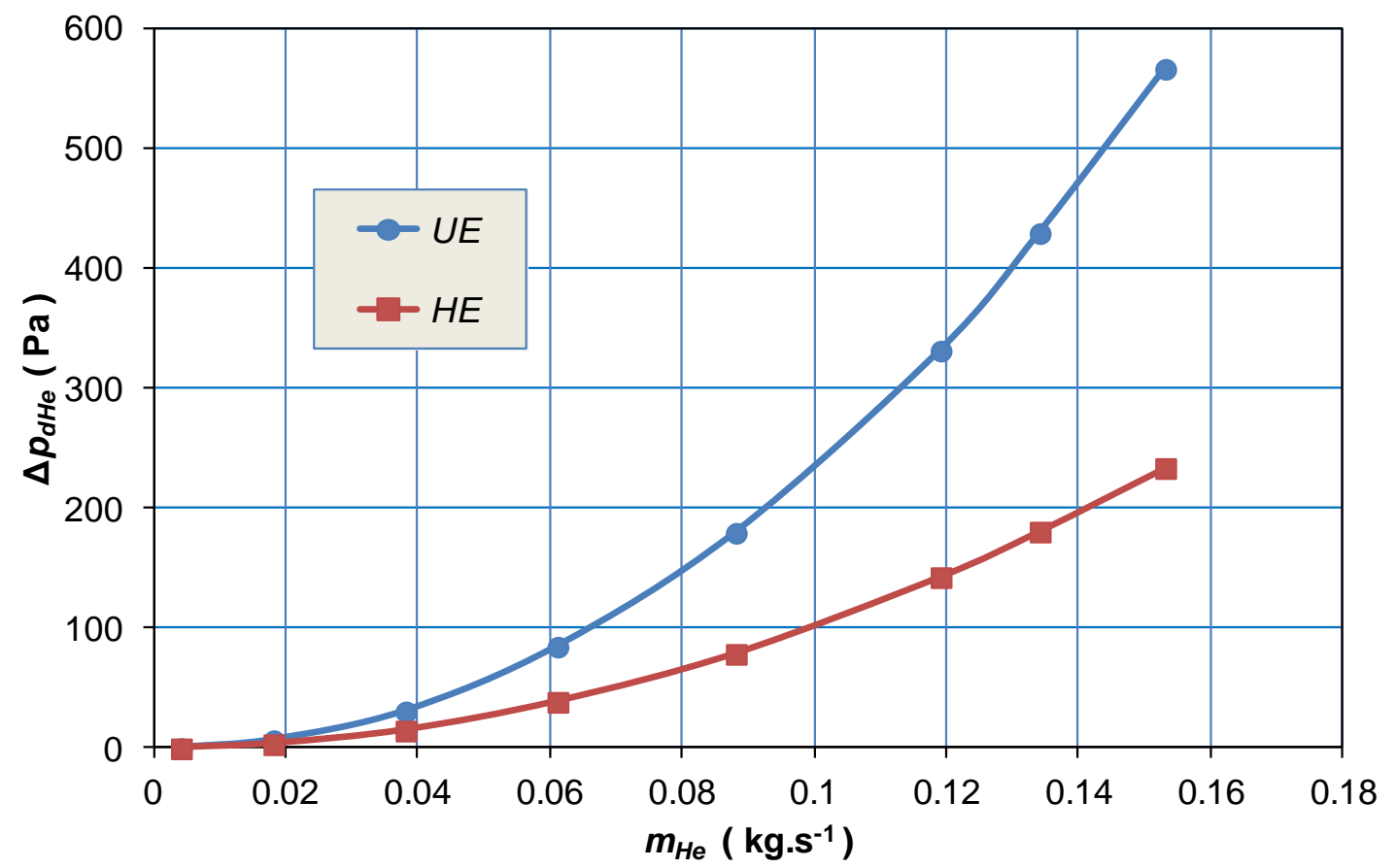

Fig. 7 The dependences of the pressure drops in the shell side of the heat exchanger with U-tubes $(U E)$ and in the helical coil heat exchanger $(H E)$ for helium on the helium mass flow rate. 




Fig. 8 The dependences of the pressure drops in the tube side of the heat exchanger with U-tubes $(U E)$ and in the helical coil heat exchanger $(H E)$ for cooling water on the mass flow rate of the cooling water.

The Fig. 9 shows the relationship between the helium mass flow rate $m_{H e}$ in the shell side of the heat exchangers and the mass flow rate of the cooling water $m_{W}$ in the tube side of the heat exchangers.



Fig. 9 The relationship between the helium mass flow rate and the mass flow rate of the cooling water in the heat exchanger with U-tubes $(U E)$ and in the helical coil heat exchanger $(H E)$. 


\section{Conclusion}

The results of the calculations document the comparison of the basic operating parameters (transferred heat flow rates between the fluids, pressure drops of the fluids) of two types of the heat exchangers (shell and tube heat exchanger with U-tubes, helical coil heat exchanger) designed for the heat removal from a high temperature helium cooling loop with steady natural circulation of helium under defined operating conditions. It follows from the above mentioned results, that the helical coil heat exchanger is more suitable from the process point of view for cooling loop with the natural circulation of the primary fluid (helium), because it achieves the higher values of transferred heat flow rates between helium and cooling water at significantly lower pressure drops for the flow of helium. A certain disadvantage of a helical coil heat exchanger is a relatively higher pressure drops for the flow of cooling water in a helically coiled tube. If necessary, this disadvantage can be eliminated by the modification of the heat exchanger design, i.e. mainly by the geometry alteration of the helically coiled tube and by the dimensions changing of the heat exchanger shell.

\section{ACKNOWLEDGEMENTS}

This contribution was created on the basis of the project "Research centre ALLEGRO" (ITMS project code: 26220220198) supported by Operational Programme Research and Development funded by the European Regional Development Fund.

\section{REFERENCES}

[1] Miletić, M., Fukač, R., Pioro, I., Dragunov, A. "Development of gas cooled reactors and experimental setup of high temperature helium loop for in-pile operation", Nuclear Engineering and Design 276, pp. 87 - 97, 2014. DOI: 10.1016/j.nucengdes.2014.04.043

[2] Berka, J., Hlinčík, T., Víden, I., Hudský, T., Vít, J. “The design and utilization of a high-temperature helium loop and other facilities for the study of advanced gas-cooled reactors in the Czech Republic“, Progress in Nuclear Energy 85, pp. 156 - 163, 2015. DOI: $10.1016 /$ j.pnucene.2015.06.003

[3] Said, I. A., Taha, M. M., Usman, S., Al-Dahhan, M. H. "Effect of helium pressure on natural convection heat transfer in a prismatic dual-channel circulation loop", International Journal of Thermal Sciences 124, pp. $162-173,2018$. DOI: $10.1016 /$ j.ijthermalsci.2017.10.004

[4] Urban, F., et al. Modelovanie prirodzenej cirkulácie hélia v experimentálnej héliovej slučke. Výskumná správa projektu Výskumné centrum ALLEGRO, Strojnícka fakulta STU v Bratislave, Bratislava, 2016.

[5] Knížat, B., Hlbočan, P., Mlkvik, M. "CFD simulation of a natural circulation helium loop“, In Scientific Proceedings Faculty of Mechanical Engineering STU in Bratislava, Nakladatel'stvo STU, Bratislava, pp. 57 - 62, 2015. DOI: 10.1515/stu-2015-0006

[6] Kutiš, V., Jakubec, J., Paulech, J., Gálik, G., Sedlár, T. “CFD Analysis of Downcomer of Nuclear Reactor VVER 440“, Journal of Mechanical Engineering - Strojnícky časopis, 66 (2), pp. 55 - 62, 2016. DOI: 10.1515/scjme-2016-0018

[7] Dzianik, F., Gužela Š. "Hydrodynamic properties of high temperature natural circulating helium cooling loop“, Journal of Mechanical Engineering - Strojnícky časopis 67 (1), pp. 29 - 36, 2017. DOI: 10.1515/scjme-2017-0003 
[8] Gužela, Š., Dzianik, F., Juriga, M., Kabát, J. "Shell and tube heat exchanger - the heat transfer area design process“, Journal of Mechanical Engineering - Strojnícky časopis 67 (2), pp. 13 - 24, 2017. DOI: 10.1515/scjme-2017-0014

[9] Dzianik, F., Gužela, Š., Puškášová, E. “Thermal characteristics of high temperature naturally circulating helium cooling loop“, Journal of Mechanical Engineering Strojnícky časopis 68 (1), pp. 5 - 14, 2018. DOI: 10.2478/scjme-2018-0001

[10] Gužela, Š., Dzianik, F. "Some facts resulting from the key variables used in the description of the recuperative heat exchangers", Journal of Mechanical Engineering Strojnícky časopis 68 (3), pp. 249 - 260, 2018. DOI: 10.2478/scjme-2018-0038

[11] "VDI-Wärmeatlas", 10th edition. VDI-Gesellschaft Verfahrenstechnik und Chemieingenieurwesen (Ed.), Springer-Verlag, Berlin - Heidelberg - New York, 2006

[12] Genić, S. B., Jaćimović, B. M., Jarić, M. S., Budimir, N. J., Dobrnjac, M. M. "Research on the shell-side thermal performances of heat exchangers with helical tube coils", International Journal of Heat and Mass Transfer 55, pp. 4295 - 4300, 2012. DOI: 10.1016/j.ijheatmasstransfer.2012.03.074

[13] Smith E. M. "Advances in Thermal Design of Heat Exchangers: A Numerical Approach: Direct-sizing, step-wise rating, and transients“, John Wiley \& Sons, Ltd, Chichester, 2005. ISBN 0-470-01616-7 